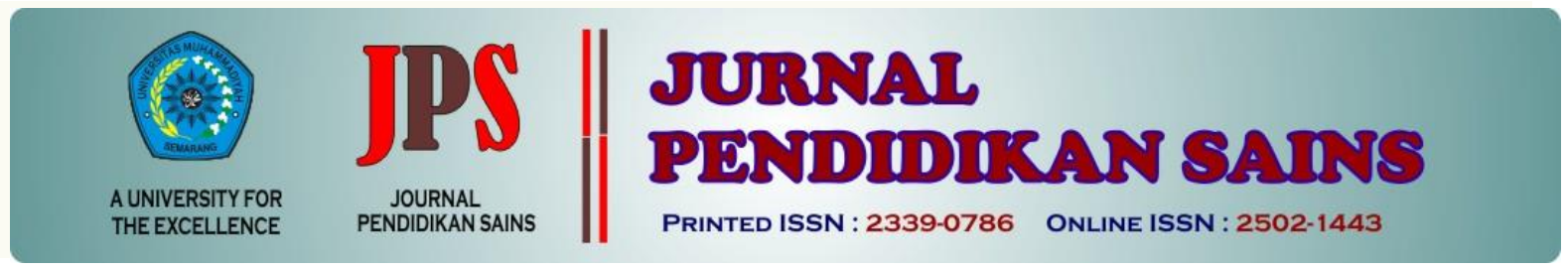

http://jurnal.unimus.ac.id/index.php/JPKIMIA

\title{
PENGARUH PENERAPAN BLENDED LEARNING DALAM MODEL PEMBELAJARAN INKUIRI TERBIMBING PADA MATERI LISTRIK STATIS TERHADAP KEMAMPUAN BERPIKIR KRITIS SISWA
}

Oleh:

Wayan Suana*, Prima Istiana, Nengah Maharta

fakultas keguruan dan ilmu pendidikan, universitas lampung email:wsuane@gmail.com

\begin{tabular}{ll}
\hline \multicolumn{2}{l}{ Article history } \\
\hline Submission & $: 2019-03-16$ \\
Revised & $: 2019-04-24$ \\
Accepted & $:$ 2019-09-03
\end{tabular}

Keyword:

Blended Learning, Static

Electricity, Critical

Thinking, Schoology

\begin{abstract}
This study aims to determine the effect of applying blended learning on static electricity material to students' critical thinking abilities. The research design used was the Pretest-Posttest Control Group Design. Data were tested by Ngain analysis, normality test, homogeneity test, and Mann-Whitney U Test. After the learning process was carried out in blended learning in the experimental class, the posttest average was 96.34, whereas in the control class using face-to-face learning, the posttest mean score was 84.64. Based on the Mann-Whitney test results, the value of Asymp. Sig. (2-Tailed) is 0,000. The average $\mathrm{N}$-gain value of critical thinking skills in the experimental class is 0.94 with a high category, while the control class with a high category is 0.74. Based on the follow-up test of the effect size test to determine the effect of the effect of applying blended learning on critical thinking skills, the effect size (d) value was 1.3 with a large category. Respondents' response to blended learning $75 \%$ of students stated that learning in blended learning helped in understanding static electricity material requires further research related to the constraints of internet networks in blended learning.
\end{abstract}

\section{Pendahuluan}

Dewasa ini, pendidikan di Indonesia menerapkan Kurikulum 2013 sebagai kurikulum yang digunakan untuk pembelajaran pada satuan pendidikan. Menurut Kemendikbud (2013:11-12) penggunanaan Kurikulum 2013 dapat menyeimbangkan antara soft skills dan hard skills dengan mengasah 3 aspek, yaitu: sikap, pengetahuan, dan keterampilan. Kurikulum 2013 juga dilengkapi dengan pendekatan scientific yaitu mengamati (observing), menanya (questioning), mengeksplorasi (exploring), mengasosiasi (associating), dan mengkomunikasikan (communicating).
Penggunaan kurikulum 2013 sesuai dengan tuntutan abad 21, dimana Kementrian Pendidikan dan Kebudayaan Republik Indonesia mengembangkan Kurikulum 2013 dengan mengadaptasi tiga konsep pendidikan abad 21 yaitu 21st Century Skills, Scientific Approach dan Authentic Assessment (Murti, 2013). Didalam konsep 21st Century Skills memuat keterampilan belajar dan berinovasi yang meliputi berpikir kritis dan mengatasi masalah, komunikasi dan kolaborasi, serta kreativitas dan inovasi (Trilling \& Fadel, 2009:49). Menurut penelitian yang dilakukan oleh Wijaya, dkk (2016: 121-123) indikator berpikir kritis dan mengatasi masalah memiliki nilai terbesar yaitu sekita 96,21\% sangat diperlukan pada keterampilan belajar abad 21 .

*Corresponding Author:

$\begin{array}{ll}\text { Nama } & \text { : Wayan Suana } \\ \text { Lembaga } & \text { : Universitas Lampung } \\ \text { Email } & \text { : wsuane@gmail.com }\end{array}$


Mata pelajaran Fisika merupakan salah satu cabang IPA. Mata pelajaran Fisika menuntut pemahaman terhadap konsep yang relatif tinggi. Keterampilan berpikir sangat diperlukan ketika mempelajari fisika, disamping keterampilan berhitung, memanipulasi dan observasi, serta keterampilan merespon suatu masalah secara kritis. Berdasarkan penelitian yang dilakukan (Maharta, 2010: 17), siswa belum paham konsep fisika yang ditandai dengan tingginya tingkat miskonsepsi fisika siswa SMA di Bandar Lampung dengan nilai rata-rata miskonsepsi fisika $65,5 \%$. Listrik statis merupakan salah satu materi dari pelajaran Fisika dan pembelajaran Fisika khususnya materi Listrik Statis masih banyak peserta didik yang mengalami kesulitan dalam memahami materi Listrik Statis (Maharta, 2010: 13-16).

Kemampuan siswa dalam memahami materi fisika ditentukan oleh proses pembelajaran di sekolah. Untuk memahami konsep materi dapat melalui pemberian pembelajaran berbasis masalah. Pembelajaran ini mengharuskan siswa untuk berpikir dan mencari dengan menintegrasikan pengalaman dan pengetahuan yang sudah dimilikinya. Hal ini sejalan dengan pendapat Ratnaningsih (2007: 15) menyatakan bahwa siswa dalam memahami konsep dan prinsip dari suatu materi memulainya dengan bekerja dan belajar terhadap situasi atau masalah yang diberikan.

Penerapan Kurikum 2013

mengharuskan pembelajaran mencakup 4C ( Critical Thinking and Problem Solving, Collaboration, Communication and Creativity and Innovation), Dalam pelaksanaannya Kurikulum 2013 ternyata terdapat hambatan seperti materi yang disampaikan terlalu banyak tetapi alokasi waktu sedikit (Mastur, 2017: 5064). Blended Learning dianggap bisa menjadi solusi untuk mengatasi kekurangan jam pelajaran karena pada pelaksanaannya bisa dilakukan diluar jam pelajaran. Penggunaan blended learning juga efektif dalam pembelajaran fisika materi listrik statis karena 75\% siswa sudah tuntas (Wulandari dkk, 2015: 32-33).

Hasil penelitian Francis dan Shannon (2013: 359-369) menyatakan bahwa penggunan blended learning dapat meningkatkan hasil belajar siswa. Selain itu, respon siswa dalam penerapan metode blended learning sangat baik dan merasa puas. Berdasarkan penelitian Hermawanto dkk, (2013: 67-76) menyatakan bahwa penguasaan konsep fisika peserta didik yang belajar menggunakan metode blended learning lebih tinggi dibandingkan penguasaan konsep peserta didik yang tidak menggunakan metode blended learning. Pembelajaran secara blended learning juga dapat memudahkan siswa untuk mengakses materi pelajaran dan meningkatkan keterampilan Teknologi Informasi dan Komunikasi (TIK) siswa (Nazrenko, 2015: 101).

Pembelajaran blended learning merupakan bagian dari mobile learning yaitu pembelajaran dengan memanfaatkan TIK sebagai media pembelajaran. Menurut (Graham Attwell, 2010:118) dalam International Journal of Mobile and Blended learning menyatakan tujuan memberikan pengenalan sistematis tentang mobile learning yang menarik untuk mengeksplorasi penggunaan perangkan mobile learning dalam belajar. Berdasarkan penelitian yang dilakukan (Nugroho \& Purwanti, 2015: 174) diperoleh bahwa pengembangan media pembelajaran berbasis mobile learning dengan pendekatan Scientific diminati oleh siswa SMP di Cirebon.

Salah satu penggunaan TIK dalam pembelajaran adalah dengan menggunakan Learning Management System (LMS). Learning Management System (LMS) merupakan suatu aplikasi atau software yang digunakan untuk mengelola pembelajaran online baik dari segi materi, penempatan, pengelolaan, dan penilaian (Mahnengar, 2012: 144-150). Ada beberapa LMS yang sering digunakan dalam pembelajaran, salah satunya adalah Schoology. Menurut (Aminoto dkk, 2014: 13-29) mengatakan bahwa Schoology merupakan website yang memadu E-Learning dan jejaring sosial. Amiroh (2013) berpendapat bahwa schoology memiliki beberapa kelebihan antara lain tersedia fasilitas absensi, yang digunakanuntuk mengecek kehadiran siswa, serta fasilitas Analytic untuk melihat semua aktivitas siswa pada setiap course, assigment, discussion, dan aktivitas lain yang kita siapkan untuk siswa.

Menurut penelitian dari Sari (2013: 3243) yang mengungkapkan strategi blended learning dapat meningkatkan kemandirian belajar dan kemampuan berpikir kritis mahasiswa era digital. Sandi (2012: 241-251), menyatakan terdapat perbedaan kemampuan berpikir kritis siswa antara pembelajaran secara blended learning dengan pembelajaran secara langsung atau tatap muka, dengan pembelajaran 
secara blended learning lebih tinggi daripada pembelajaran langsung.

Berdasarkan pemaparan diatas terkait pentingnya siswa memiliki kemampuan berpikir kritis dalam pendidikan abad 21 dan sesuai dengan kurikulum 2013 revisi yang berlaku di Indonesia serta banyaknya pemanfaatan teknologi Informasi dan komunikasi (TIK) dalam bidang pendidikan salah satunya penggunaan model pembelajaran blended learning yang memanfaatkan schoology sebagai Learning Management system (LMS) dalam pembelajaran, maka peneliti telah melakukan penelitian eksperimen yang bertujuan untuk mengetahui pengaruh penerapan blended learning pada materi listrik statis terhadap kemampuan berpikir kritis siswa dan melihat respon siswa terhadap pembelajaran blended learning menggunakan schoology.

\section{Metode Penelitian}

Jenis Penelitian

Penelitian ini menggunakan jenis penelitian penelitian eksperimen semu atau quasi-experiment dengan desain pretestposttest control group design.

\section{Waktu dan Tempat Penelitian}

Penelitian eksperimen ini bertempat di SMA Negeri 1 Kalianda, Lampung Selatan dengan populasi siswa seluruh kelas XII MIA dan sampel penelitian kelas XII MIA 1 yang berjumlah 32 siswa dan kelas XII MIA 2 yang berjumlah 28 siswa, semester ganjil tahun ajaran 2018/2019.

Prosedur

Prosedur pengambilan sampel menggunakan teknik purpse sampling yang dilakukan dengan cara memilih dua kelas yang rata-rata kemampuannya sama untuk dipilih sebagai sampel, dan diperoleh Kelas XII MIA 2 yang berjumlah 32 siswa sebagai kelas eksperimen yang akan menerapkan pembelajaran secara blended learning dan Kelas XII MIA 1 yang berjumlah 28 siswa sebagai kelas kontrol yang menerapkan pembelajaran langsung (tatap muka saja). Prosedur pelaksanaan penelitian pada kelas eksperimen meliputi pretest - online - tatap muka - online - posttest sedangkan dikelas kontrol pretest - tatap muka - posttest.

Instrumen Penelitian

Instrumen Penelitian yang digunakan pada penelitian ini yaitu instrumen kemampuan berpikir kritis berupa soal pilihan jamak yang terdiri dari 15 tentang materi Listrik Statis yang dikembangkan oleh peneliti sebelumnya Damayanti dkk, (2019: 2-6) dan terdapat instrumen angket analisis kebutuhan siswa terhadap pembelajaran blended learning yang sudah diikuti mereka.

\section{Teknik Analisis Data}

Selanjutnya untuk analisis data pada penelitian ini meliputi uji validitas soal dan reliabilitas yang dilakukan sebelum soal digunakan ke sampel penelitian. Uji validitas soal instrumen menggunakan uji pearson. Uji validitas instrumen soal berpikir kritis memperoleh skor correlated item - total correlation yang menunjukan $>0,3$ sehingga instrumen soal-soal tersebut dikatakan valid. Karena $r_{\text {hitung }}>r_{\text {tabel }}$ maka dikatakan data tersebut valid sedangkan uji reliabilitas Sedangkan uji reliabilitas menggunakan uji reliability dapat dilihat pada nilai Alpha Cronbach yang menunjukan angka 0,412 sehingga instrumen tersebut dapat dikatakan cukup reliabel. Selanjutnya setelah instrumen berpikir kritis dinyatakan valid dan reliabel, instrumen digunakan untuk pretest dan posttest. Kemudian data diuji normalitas dan homogenitas, setelah diuji normalitas dan diperoleh bahwa data berdistribusi normal dan setelah dilakukan uji homogen diperoleh data tidak homogen sehingga dilakukan uji statistik non parametrik yaitu uji Mann Whitney U Test untuk mengetahui perbedaan model yang diterapkan dan melakukan uji effect size sebagai uji lanjutan untuk mengetahui besar efek yang ditimbulkan dari pengaruh pembelajaran blended learning pada materi listrik statis terhadap kemampuan berpikir kritis siswa.

\section{Hasil Penelitian dan Pembahasan}

Hasil penelitian terdiri dari hasil kuantitatif berupa nilai pretest dan posttest kemampuan berpikir kritis dan hasil data kualititatif berupa angket pembelajaran blended learning menggunakan schoology. 
Hasil Uji Istrumen Penelitian

Sebelum instrumen di ujikan ke siswa, terlebih dahulu instrumen di uji validitasnya menggunakan SPSS untuk mengetahui kevalidan soal dan diperoleh 15 soal valid. Pengujian reliabilitas untuk mengetahui tingkat reliabilitas soal dan diperoleh nilai sebesar 0,421 dengan taraf cukup reliabel.

Tahap Pelaksanaan

Tahap pelaksanaan penelitian terdiri dari dua kelas yaitu kelas eksperimen dan kelas kontrol. Pertemuan terdiri dari 3 pertemuan pada kelas eksperimen dan kelas kontrol.
Pada kelas eksperimen yang terdiri dari 28 siswa kelas XII MIA 2 cara pembelajarannya secara blended learning sedangkan pada kelas kontrol yaitu kelas XII MIA 1 menggunakan pembelajran secara langsung atau tatap muka. Dalam pelaksanaannya, kedua kelas mengggunakan model inkuiri terbimbing.

\section{Data Kuantitatif Hasil Penelitian}

Tes kemampuan berpikir kritis siswa diambil dari hasil pretest dan posttest, sehingga memperoleh hasil seperti pada tabel 1 .

Tabel 1. Hasil Tes Kemampuan Berpikir Kritis Siswa

\begin{tabular}{lccccc}
\hline \multirow{3}{*}{ Kelas } & \multicolumn{5}{c}{ Kemampuan Berpikir Kritis } \\
\cline { 2 - 6 } & jenis tes & nilai maks & nilai min & Rata-rata & sd \\
\cline { 2 - 6 } Eksperimen & pretest & 67 & 20 & 40,59 & 11,66 \\
& posttest & 100 & 73 & 96,34 & 5,70 \\
\cline { 2 - 6 } Kontrol & pretest & 53 & 13 & 36,11 & 13,62 \\
& posttest & 100 & 67 & 86,64 & 9,26 \\
\hline
\end{tabular}

Berdasarkan tabel hasil tes kemampuan berpikir kritis siswa memperoleh data skor maksimum lebih besar diperoleh pada kelas eksperimen dibandingkan kelas kontrol begitu pula skor minimum yang diperoleh lebih besar kelas eksperimen dibandingkan kelas kontrol dan skor rata-rata kelas eksperimen lebih besar dibandingkan dengan kelas kontrol. Untuk mengetahui nilai $N$-gain pada kemampuan berpikir kritis siswa dapat dilihat pada tabel 2 .

Tabel 2. Data rata-rata $N$-gain Kemampuan Berpikir Kritis Siswa

\begin{tabular}{lcc}
\hline \multicolumn{1}{c}{ Perolehan Skor } & Kelas Eksperimen & Kelas Kontrol \\
\hline Gain Tertinggi & 1 & 1 \\
Gain Terendah & 0,66 & 0,62 \\
Rata-rata Gain & 55,75 & 48,54 \\
Rata-rata $N$-gain & 0,94 & 0,76 \\
Kategori & Tinggi & Tinggi \\
\hline
\end{tabular}

Setelah dilakukannya pretest dan posttest kemudian dihitung rata-rata $n$-gain untuk melihat peningkatan kemampuan siswa dalam pembelajaran yang telah diikuti sehingga diperoleh skor $n$-gain kemampuan berpikir kritis kelas eksperimen memperoleh skor 0,94 dan kelas kontrol memperoleh skor 0,76 . Sehingga dapat dikatakan rata-rata- n-gain kelas eksperimen lebih besar dibandingkan kelas kontrol dengan kritera sedang menurut (Hake,2002).

Pengujian normalitas dan homogenitas dilakukan setelah mendapat data n-gain. Berdasarkan perhitungan untuk variabel kemampuan berpikir kritis memperoleh skor normalitas kelas eksperimen 
sebesar 0,071 dan kelas kontrol memperoleh skor 0,177 . Berdasakan hasil uji analisis yang didapat data-data tersebut dikatakan normal karena memenuhi kriteria uji normalitas yaitu jika sig > 0,05 maka data berdistribusi normal. Sedangkan homogenitas variabel kemampuan berpikir kritis memperoleh skor 0,000 Sehingga dapat dikatakan bahwa data tidak homogen karena signifikan $<0,05$ maka data tidak memiliki varian yang sama.

Berdasarkan uji Normalitas dan Homogenitas data tidak memenuhi untuk dilakukan Uji Parametrik menggunakan uji Independent Sample t Test Sehingga dilakukan uji non parametrik yaitu menggunakan uji Mann-Whitney $U$ Test untuk mengetahui apakah perbedaan peringkat kedua kelompok yaitu kelas eksperimen dan kelas kontrol dalam penelitian bermakna secara statistik atau siginifikan. model pembelajaran yang diterapkan di penelitian dengan menggunakan calculator cohen's $d$. Berdasarkan uji lanjutan yaitu uji effect size untuk mengetahui efek besarnya pengaruh penerapan blended learning terhadap kemampuan berpikir kritis diperoleh niali effect size (d) sebesar 1,3 dengan kategori besar. Hal ini sesuai dengan penelitian (cohen's, 1994: 997) yaitu membagi rentang effect size dalam beberapa kategori dimana $\mathrm{d}>0,8$ termasuk dalam kategori efek besar. Data yang diperoleh membuktikan bahwa model pembelajaran blended learning dapat mempengaruhi kemampuan berpikir kritis siswa.

Untuk melihat tanggapan atau respon siswa terhadap pembelajaran blended learning menggunakan schoology peneliti menggunakan angket analisis kebutuhan pembelajaran blended learning pada Tabel 3.

Tabel 3. Respon Siswa Terhadap Pembelajaran Blended Learning

\begin{tabular}{lcccc}
\hline \multirow{2}{*}{ No } & \multirow{2}{*}{ Kategori } & \multicolumn{3}{c}{ Tanggapan Siswa } \\
\cline { 2 - 5 } & & Kemenarikan & Kemudahan & Manfaat \\
\hline 1 & STS & $1(0,52 \%)$ & $9(4,02 \%)$ & $4(1,56 \%)$ \\
2 & TS & $7(4,17 \%)$ & $29(12,95 \%)$ & $18(7,03 \%)$ \\
3 & R & $58(30,21 \%)$ & $63(28,12 \%)$ & $105(41,02 \%)$ \\
4 & S & $107(55,73 \%)$ & $107(47,77 \%)$ & $112(43,75 \%)$ \\
5 & SS & $18(9,37 \%)$ & $16(7,14 \%)$ & $16(6,25 \%)$ \\
\hline
\end{tabular}

Keterangan:

$$
\begin{aligned}
& \text { STS }=\text { Sangat Tidak Setuju } \\
& \text { TS }=\text { Tidak Setuju } \\
& \mathrm{R}=\text { Ragu-Ragu } \\
& \mathrm{S}=\text { Setuju } \\
& \mathrm{SS}=\text { Sangat Setuju }
\end{aligned}
$$

Berdasarkan perhitungan variabel kemampuan berpikir kritis menggunakan Mann-Whitney U Test memperoleh sig sebesar 0,00 sehingga dari skor yang diperoleh dapat dikatakan terdapat perbedaan antara kedua kelas eksperimen dan kontrol dengan menggunakan pembelajaran yang berbeda. Kedua kelas dinyatakan terdapat perbedaan karena sesuai dengan kriteria uji Mann-Whitney $U$ Test yang dimana jika sig $<0,05$ maka $\mathrm{H}_{0}$ ditolak atau terdapat perbedaan antara kelas eksperimen dan kelas kontrol.

Setelah kedua data memiliki perbedaan terhadap hasil n-gain dilakukanlah uji effect size dilakukan untuk melihat besar ukuran pengaruh
Berdasarkan Tabel 3, diketahui tanggapan siswa untuk pembelajaran blended learning menggunakan schoology rata-rata siswa memilih setuju jika pembelajaran secara blended learning diterapkan di sekolah, meskipun demikian banyak juga siswa yang memilih ragu-ragu apakah pembelajaran secara blended learning dapat diterapkan disekolah hal tersebut dipengaruhi oleh jaringan internet di tempat tinggal masing masing berbeda dan kuota data yang digunakan untuk mengakses schoology dikarenakan kebanyakan mereka mengakses menggunakan android.

Berdasarkan hasil data penelitian pembelajaran blended learning dapat 
meningkatkan kemampuan berpikir kritis siswa. Pembelajaran blended learning pada kelas eksperimen yang dilakukan menggunakan model inkuiri terbimbing. Langkah langkah pembelajaran blended learning pada kelas eksperimen yaitu online learning - tatap muka - online learning untuk satu kali pertemuan (Suana 2017: 170-178). Pada saat online learning kelas eksperimen menggunakan Learning Managenet System (LMS) berupa Schoology yang dapat membantu siswa-siswi berinteraksi, saling bertukar pikiran, bertanya dan menyamapaikan ide masing-masing siswa yang dipandu oleh guru.

Shoology merupakan salah satu LMS berbentuk web sosial yang menawarkan pembelajaran sama seperi di dalam kelas secara gratis dan mudah digunakan (Putri, dkk. 2014: 1-11). Selain itu Sholoology memiliki bebrapa kelebihan antara lain, pada Schoology tersedia fasilitas Attandance Atau absensi yang digunakan untuk mengecek kehadiran siswa, serta fasilitas Analytic untuk melihat semua aktivitas siswa pada setiap course, assigment, discussion, dan aktivitas lain yang kita siapkan untuk siswa.

Penggunaan Shoology pada saat diskusi online sebelum tatap muka dilakukan dengan memberikan masalah berupa pengamatan video fenomena mengenai materi listrik statis. Setelah pemberian masalah berupa video, setiap kelompok berdiskusi merumuskan masalah terkait video yang diberikan kemudian menentukan rumusan dan hipotesis dari permasalahan mengenai materi listrik statis.

Pembelajaran secara blended learning dimaksudkan untuk mengefektifkan waktu pembelajaran yang singkat disekolah, sehingga siswa lebih leluasa mengerjakan tugas kapan dan dimana saja. Hal tersebut sesuai dengan tanggapan terhadap hasil angket analisis pembelajaran blended learning menggunakan scholoogy yang diperoleh 18 orang dari 32 menyatakan pembelajaran secara blended learning mudah dilakukan kapan saja dan dimana saja. Selain itu penggunaan schoology sebagai forum diskusi juga memungkin untuk semua anak dapat berpartisipasi penuh. Hal tesebut senada dengan yang diungkapkan oleh Birch dan Volkv (2007: 291-306) bahwa forum online dapat mendorong siswa tertentu yang mungkin enggan untuk berbicara secara langsung namun mereka tetap dapat terlibat dalam diskusi mampu mendorong siswa untuk lebih banyak bertanya terhadap kesulitan yang siswa alami.
Dalam pelaksanaannya pembelajaran materi listrik statis dilakukan secara blended learning untuk mengefektifkan waktu pembelajaran disekolah dengan menggunakan model inkuiri terbimbing. Sintaks inkuiri terbimbing meliputi enam tahapan yaitu menyajikan pertanyaan (orientasi masalah), perumusan masalah, membuat hipotesis, mengumpulkan data, menganalisis data dan membuat kesimpulan. Pembelajaran menggunakan model inkuiri terbimbimbing menekankan pada proses berpikir yang berstandarkan pada proses belajar dan hasil belajar serta mengembangkan seluruh potensi siswa termasuk kemampuan berpikir kritis. Sejalan dengan penelitian (Masitoh dkk., 2017: 71-79) yang menyatakan bahwa model pembelajaran inkuiri terbimbing berpengaruh terhadap kemampuan berpikir kritis siswa. Setiap tahapan dari sintak inkuiri terbimbing mampu mengembangkan kemampuan berpikir kritis.

Penggunaan model inkuiri terbimbing yang memiliki banyak tahapan memakan waktu pembelajaran yang tidak sedikit. Adapun tahapan inkuiri terbimbing pada penelitian yang digunakan mengacu pada LKPD yang dikembangkan oleh Alexandro dkk, (2017:7584) antara lain orientasi masalah, perumusan masalah dan menentukan hipotesis sementara dikerjakan secara online, sedangkan tahap pengumpulan data, analisis data dan kesimpulan dikerjakan pada pertemuan tatap muka di sekolah dan kegiatan penutup dilakukan secara online.

Menurut penelitian dari Sari (2013: 32-43) yang mengungkapkan strategi blended learning dapat meningkatkan kemandirian belajar dan kemampuan berpikir kritis mahasiswa di era digital. Sandi (2012: 241251) menyatakan terdapat perbedaan kemampuan berpikir kritis siswa antara pembelajaran secara blended learning dengan pembelajaran secara langsung atau tatap muka, dengan pembelajaran secara blended learning lebih tinggi daripada pembelajaran langsung. Berdasarkan hasil angket analisis kebutuhan siswa terhadap pembelajaran secara blended learning banyak yang setuju namun masih banyak siswa yaitu rata rata hampir 50\% siswa yang masih ragu ragu apakah pembelajaran secara blended learning mudah dilaksanakan.

Berdasarkan isian angket terbuka tentang pembelajaran blended learning diketahui alasan siswa menjawab ragu-ragu terkait pembelajaran secara blended learning 
dikarenakan kendala jaringan dan kuota. Mengingat tidak semua siswa tinggal di Kalianda, beberpa mereka tinggal di desa dan mengeluhkan buruknya jaringan internet, belum lagi kuota data yang digunakan. Sehingga hal tersebut membuat mereka malas untuk mengakses schoology meskipun cara aksesnya mudah dan dapat dilakukan dimana saja. Selain itu mereka berpendapat jika pembelajaran secara langsung lebih mudah dipahami karena siswa dapat bertanya langsung kepada guru jika tidak paham.

\section{Simpulan dan Saran}

Simpulan

Berdasarkan hasil penelitian yang telah dilakukan, maka dapat disimpulkan terdapat perbedaan yang signifikan setelah diterapkan pembelajaran blended learning pada materi listrik statis terhadap kemampuan berpikir kritis siswa dibandingkan pembelajaran secara langsung (tatap muka saja). Hal ini dapat dilihat dari rata-rata n-gain kelas eksperimen lebih besar dibandingkan kelas control dan pengaruh blended learning terhadap kemampuan berpikir kritis yang dilihat dari perhitungan effect size yang diperoleh nilai sebesar 1,3 dengan kategori besar, sehingga penerapan blended learning dapat meningkatkan kemampuan berpikir kritis siswa.

Saran

Berdasarkan kesimpulan maka peneliti dapat merekomendasikan terhadap penerapan blended learning pada materi listrik statis terhadap kemampuan berpikir kritis yaitu pembelajaran blended learning dapat menjadi salah satu alternatif untuk meningkatkan kemampuan berpikir kritis siswa tetapi pada aktivitas online perlu dipertimbangkan waktu dan kadaan, karena dalam pelaksanaannya siswa memerlukan jaringan dan kuota data yang memadai. Berdasarkan hal tersebut semoga penelitian ini dapat dijadikan bahan kajian oleh peneliti lain.

\section{Daftar Pustaka}

Alexandro, I., Maharta, N., \& Suana, W. (2017). Pengembangan Perangkat Blended Learning Berbasis LMS dengan Model Pembelajaran Inkuiri Pada Materi Listrik Statis. Prosiding Seminar
Nasional Pendidikan FKIP UNTIRTA. Universitas Lampung: Bandarlampung.

Aminoto, T., Pathoni, H. 2014. Penerapan Media E-Learning Berbasis Schoology untuk Meningkatkan Aktivitas dan Hasil belajar Materi Usaha dan Energi di Kelas XI SMKN 10 Kota Jambi. Jurnal Sainmatika, 8(1), 13-29.

Amiroh. 2013. Under E-Learning Edmodo, Moodle and Schoology, (Online), (http://amiroh.web.id), diakses 3 September 2018.

Birch, D., \& Volkov, M. (2007). Asesment of online reflections: Enganging English second language (ESL) students. Australasian. Journal of Educational Technology, 23(3), 291-306.

Cohen, J. (1994). The Earth is Around ( $5<.05)$. American Psychologist. 49:997-1003.

Damayanti, T., Suana, W., Herlina K., \& Distrik, I W. (2019). Development Of Critical Thinking Instrument Of Electricity For Senior High School Students. Journal of Phisics, (1157).

Francis, R., \& Shannon, S.J. (2015). Engaging With Blended Learning to Improve Students' learning Outcomes. European Journal of Engineering Education, 38(2), 359-369.

Graham, A., Norbert, P., \& Christoph P. 2010. Toward Work-Based Mobile Learning: What We Can Learn From The Field Of Work-Based Learning And Mobile Learning. International Journal of Mobile and Blended Learning, 2(4), 118.

Hake, R.R. (2002). Relationship of Individual Student Normalized Learning Gains in Mechanics with Gender, High School Physics, and Pretest Scores on conference; Boise, Idaho. Diakses pada tanggal 7 Septemmber 2018 dari http://www.physics.indiana.edu/ hake.

Hermawanto., Kusairi,S., \& Wartono. (2013). Pengaruh Blended Learning Terhadap Penguasaan Konsep dan Penalaran Fisika Peserta Didik Kelas X. Jurnal Pendidikan Fisika Indonesia 9 (2013) 67-76.

Kementrian Pendidikan dan Kebudayaan. (2013). Paparan Pengembangan Kurikulum 2013. Jakarta.

(2014). Konsep dan Implementasi Kurikulum 2013. Jakarta.

Maharta, N. (2010). Analisis Miskonsepsi Fisika Siswa SMA di Bandar Lampung. Diakses pada tanggal 7 September 2018 
dari

https://id.scribd.com/doc/41470237/Jurna 1-Analisis-Miskonsepsi-Fisika.

Mahnengar, F. 2012. Learning Management System. International Journal of Business and Social Science, 3(12), 144150.

Masitoh, D. I., \& Marjono. Ariyanto, J. (2017). Pengaruh Model Pembelajaran Inkuiri Terbimbing Terhadap Kemampuan Berpikir Kritis Siswa Kelas X MIA Pada Materi Pencemaran Lingkungan di Surakarta. Jurnal Bioedukasi, 10 (1), 71 79.

Mastur. (2017). Implementasi Kurikulum 2013

Dalam Pelaksanaan Pembelajaran di SMA. Jurnal Inovasi Teknologi Pendidikan, 4(5), 50-64.

Murti, M. (2013). Pendidikan Abad 21 dan Implementasinya Pada Pembelajaran di SMK untuk Paket Keahlian Desai Interior. Artikel Kurikulum 2013 SMK.

Nazarenko, A. L. (2015). Blended Learning vs Traditional Learning: What Works? Social and Behavioral Sciences, 200.

Nugroho, A., Purwati, H. 2015. Pengembangan Media Pembelajaran Matematika Berbasis Mobile Learning Dengan Pendekatan Scientific. Jurnal Euclid, 2(1), 174-182.

Putri. Ananda, M. N. W., Jampel, N., \& Suartama, I. K. (2014). Pengembangan E-Learning Berbasis Schoology pada mata pelajaran IPA Kelas VIII di SMP Negeri 1 Seririt. Jurnal Edutech Universitas Pendidikan Ghanesa, 2 (1), $1-11$.
Ratnaningsih, N. (2007). Pengaruh Pembelajaran Kontekstual terhadap Kemampuan Berpikir Kritis dan Kreatif Matematik Siswa Sekolah Menengah Atas. Sitasi, Universitas Pendidikan Indonesia. Bandung.

Sandi, G. (2012). Pengaruh Blended Learning Terhadap Hasil Belajar Kimia Ditinjau dari Kemandirian Siswa. Jurnal Pendidikan dan Pengajaran, 45 (3), 241251.

Sari, AS. (2013). Strategi Blended Learning Untuk Peningkatan Kemandiria Belajar dan Kemampuan Critical Thinking Mahasiswa di Era Digital. Jurnal Pendidikan Akuntansi Indonesia, Vol.XI, No.2 Tahun 2013 32-43

Suana,W., Maharta, N., Nyeneng, I.D., \& Wahyuni, S. (2017). Design And Implementation Of Schoology Based Blended Learning Media For Basic Physics I Course. Jurnal Pendidikan IPA Indonesia. 6(1). 170-178.

Trilling, B., \& Fadel, C. (2009). $21^{\text {st }}$ Century Skills, Learning for life in our times, John Wiley \& Sons, 978-0-47-055362-6.

Wijaya, Y. E., Sudjimat, A., \& Nyoto, A. (2016). Transformasi Pendidikan Abad 21 Sebagai Tuntutan Pengembangan Sumber Daya Manusia di Era Global. Prosiding Seminar Nasional Pendidikan Matematika $2016 \quad$ Universitas Kanjuruhan Malang.

Wulandari, S. R., Suyanto, E., \& Suana,W. (2016). Modul Interaktif dengan Learning Content Development System materi pokok listrik statis. Jurnal Pendidikan Fisika. 